\title{
Recenzió Benczes István: Válság és válságrendezés a Gazdasági és Monetáris Unióban címü könyvéről
}

Benczes István, a Budapesti Corvinus Egyetem Világgazdasági Tanszékének egyetemi tanára 2021. márciusban védte meg MTA doktori disszertációját, mely a könyv alapjául szolgál. Témája rendkívül időszerü. Az elmúlt évtizedekben hozzászokhattunk ahhoz, hogy az egymást követő válságok (alkotmányozás, pénzügyi válság, menekültválság, Brexit, populizmus, járvány) során katasztrófaforgatókönyveket hallgatunk arról, hogy az integráció gyengül, és az Európai Unió hamarosan szétesik. Emellett az integráció mélyüléséről is kapunk híreket, hisz újabb és újabb területeken jelentenek be intézkedéseket a válságok lecsengése után. Benczes István munkájának legfontosabb erénye, hogy képes az egymástól távol álló narratívákat egyetlen elméleti keretbe összefoglalni.

A szerző arra a központi kérdésre keresi a választ, hogy „miként alakult az európai integráció a válságrendezés során?” (21. o.). Ennek a problémának az egyik alkérdése, hogy „miért választanak a felek (látszólag) szuboptimális megoldásokat” (22. o.). Az irodalomban ritkán adnak szofisztikált válaszokat ezekre a kérdésekre. Az európai integráció hívei a válságokban hagyományosan lehetőséget látnak - hisz kivételes időszakokban olyan lépések is lehetővé válnak, amelyek békeidőben esélytelenek. Benczes István azonban arra hívja fel a figyelmet, hogy az elmúlt évtizedben ez nem teljesen így alakult, és a válságokra adott válaszok egy jóval differenciáltabb képet mutatnak.

A szerző már a bevezető fejezetben felvázol egy elméleti keretet, amelyben a különféle válságok értelmezhetővé válnak. Két dimenzióban (centralizáció és kooperáció) négy lehetséges integrációs utat mutat be: dezintegráció, inkrementális reform, hegemónia és mélyülés. A könyv empirikus fejezeteiben az európai válságkezelés gyakorlatát ezekbe a kategóriákba helyezi el.

Az elméleti keret megalapozását szolgálja a 2. és 3. fejezet nagyívű áttekintése az integrációelméletekről. A szerző kritikai szemmel, történeti kontextusban mutatja be az európai integráció megértéséhez legfontosabbnak tekintett elméleteket: a neofunkcionalizmus, történeti institucionalizmus, illetve a kormányköziség fő kérdéseit, fogalmait és megállapításait.

Az alapos elméleti áttekintést követik az empirikus fejezetek. A 4. fejezet a dezintegráció esetét tárgyalja. Először egy érdekes gazdaságtörténeti áttekintés alapján bemutatja azt, hogy a monetáris uniók fennmaradása elsősorban a támogató politikai akarat függvénye. Az eurózóna kapcsán az optimális valutaövezetek elméletének felhasználásával rámutat arra, hogy az alacsony mértékü költségvetési újraelosztás, a végső hitelezői funkciók hiánya és a konvergencia elmaradása miatt nem beszélhetünk optimális valutaövezetről. Görögország esetének költség-haszon elemzése alapján azonban arra a következtetésre jut, hogy ebből a megfontolásból önmagában még egyáltalán nem következik a szétesés vagy az, hogy a kilépés jó döntés lenne. A dezintegráció ettől függetlenül egy létező veszély, amint a Brexit is jelzi. Ennek megértéséhez a belső politika elemzése szükséges - a 2010-es években megerősödtek azok a szereplök, akik a dezintegrációt pártolják.

Az 5. fejezet a kis lépések stratégiájáról szól, azaz az inkrementális reformokról. Ez a stratégia a határozottabb mélyülés alternatívája, amikor az integráció szükségessé teszi az előrelépést, ám hiányzik hozzá a politikai akarat. Ennek egyik fó példája a görög adósságválság kezelése, amikor számos forduló volt szükséges a megoldáshoz, és a tárgyalások során a tagállamok és nem a Bizottság, azaz a nemzetek 
feletti szerv, játszotta a fő szerepet. A tárgyalások kapcsán a szerző kiválóan írja le a folyamatokat játékelméleti modellek segítségével. A második példa az Európai Stabilitási Mechanizmus kialakulása, aminek a támogatása csak szigorú feltételesség mellett elérhető. Ám az európai IMF létrehozását épp a németek ellenzik, és fenntartják az igényt, hogy a jövendő mentőcsomagokról véleményt mondjanak. A fejezet harmadik példája a Fiskális Paktum, ami a Stabilitási és Növekedési Egyezmény egyfajta szigorításaként értékelhető, de ennek kialakítása során sem a Bizottság szint játszotta a fö szerepet, hanem a tagállamok.

A 6. fejezet azt a kérdést vizsgálja, hogy mennyiben hajlandó magára vállalni Németország a hegemón szerepet. Ebben a részben különösen érdekes a hegemónia liberális és realista megközelítésének összevetése. Míg az előbbi a hegemónt egy jóságos szereplőnek tekinti, amely a közösség részére közjavakat biztosít, utóbbi szerint a hegemón az erő pozíciójából biztosítja a rendszer nyitottságát és stabilitását. Az EU eredetileg arra jött létre, hogy ne lehessen egyetlen hegemón se, de az újraegyesült Németország az EU legnagyobbjaként egyfajta természetes hegemónnak tekinthető. Ennek ellenére a hegemón szereptől kifejezetten vonakodik, és az integráció során Németország mindig ragaszkodott ahhoz, hogy partnereivel megossza a terheket és a felelősséget is. A vonakodó hegemón szerepe a pénzügyi válság során is elökerült, hiszen Németország ellenállt a feltételek nélküli kimentés ötletének csakúgy, mint az eurókötvényeknek. A szerző ennek magyarázatát a német ordoliberalizmus és a francia keynesianizmus különbségében látja. Németország értelmezésében az EU szabályokat és normákat ír elő, amik hosszabb távon mindenki előnyére válnak. A német hegemónia felvállalását korlátozza a szélsőséges AFD megerősödése is, ami szigorúan kritizál minden lépést, ami a német adófizetők pénzét veszélyezteti. Mindez azonban hamarosan megkérdőjelezheti azt az axiómát, hogy a németek európaisága miatt mindig lehet rájuk számítani az integráció előmozdításában.

Talán ez a fejezet a legérdekesebb, és itt merül fel a legtöbb kérdés. Bár Benczes István nem foglal egyértelmüen állást, az olvasó mégis azt érezheti, hogy a valódi integrációhoz feltételek nélküli kimentésekre és eurókötvényre lenne szükség. Ez azonban erősen vitatható. Akár Kelet-Németországra, akár Dél-Olaszországra gondolunk, a feltételek nélküli transzfereknek jelentős kockázata van. A szerző nem foglal állást abban a vitában sem, hogy a gazdasági teljesítmény alapján a német vagy a francia rendszer a hatékonyabb - az erről való reflexió azért is lett volna érdekes, mivel ebből ítélhető meg az, hogy érdemes-e erőltetni a német szabályalapú rendszert vagy sem.

A 7. fejezet a mélyülés folyamatát tárgyalja két eltérő eseten keresztül: míg a bankunió létrehozása komoly sikernek tekinthető, a fiskális unióhoz hiányzik a politikai akarat. Ebben a fejezetben központi kérdésként merül fel, hogy miért történt áttörés az egyik esetben, és miért maradt el a másik esetben. A szerző részletes áttekintést nyújt a bankunió körüli vitákról és ezek megoldásáról. Arra a következtetésre jut, hogy ott volt sikeres a reform, ahol a tagállamok érdekei konvergáltak, és a pénzügyi válság rászorította a szereplöket a megállapodásra. A bankunióval kapcsolatos leírás részletes és alapos, ám a végén az olvasónak mégis hiányérzete van, mert kimaradt belőle egy fontos pillér: mi történt az európai szintü betétbiztosítási rendszerrel? Mennyiben befolyásolja ennek kudarca a bankunió sikerének megítélését?

A 7. fejezet másik esete a fiskális unió kudarca. A szerző alapos áttekintést nyújt a fogalom értelmezése körüli vitákról. Rámutat arra, hogy a szolidaritásra épülő fiskális unió egyfajta előfeltétele a nemzeti szintű fiskális szabályok bevezetése. Amellett érvel, hogy utóbbi egy kockázatmegosztó mechanizmus, ami nem csupán a déli, hanem az északi államok számára is segítséget jelenthet az üzleti ciklus leszálló ágában (263264. o.). Ez azonban meglehetősen erős feltevésnek tünik - ha azonos eséllyel kerülhet bajba minden 
tagállam, akkor miért ne lenne elégséges nemzeti szintű anticiklikus politikát folytatni, aminek során minden tagállam tartalékol az üzleti ciklus felívelő szakaszában a nehezebb időkre? A kudarc magyarázataként a szerző kiemeli a tagállami költségvetési politikák komoly különbségeit, és arra is rámutat, hogy a kormányzás minősége magasabb adókat tesz lehetővé a munkavállalók és a vállalatok felé (272. o.). Más országok a kormányzási minőség hátrányait kompenzálják alacsony adókkal. A fejezet végén a közös költségvetés lehetséges területeiről esik szó, melyek közül kiemelendő a védelmi kiadások emelésének a szükségessége. A fiskális unió azonban még ma is messze van.

Benczes István mindenütt távolságtartóan ír az integráció fejleményeiről, azonban nem lehet nem észrevenni, hogy a fiskális uniót milyen lényegesnek tartja, és a német vonakodást a kérdésben mintha nehezményezné. Talán érdemes lett volna bővebben kifejteni, hogy a németek miért is vonakodnak a fiskális uniótól az adófizetőik pénzének spórolásán túlmenően. Az adók beszedése és a kormányzás minősége közötti összefüggés könnyen továbbgondolható. Amikor a transzferek növelését ösztönözzük, akkor nem lehet eltekinteni attól a kérdéstől, hogy ez javít vagy ront a kormányzás minőségén - ha az utóbbi, akkor kifejezetten káros lehet növelni az átutalásokat.

A 8. fejezet egy összegzést nyújt a kötet legfontosabb megállapításairól. A legfontosabb következtetés, hogy az integráció közösségi módszere a válságkezelés során háttérbe szorult, és felerösödtek a kormányközi megoldások. Ám a közösségi módszer sem tűnt el - a kormányközi megoldások is elsősorban a konszenzuskeresésről és nem az esetleges erőfölény kihasználásáról szóltak. Mindez összességében egyáltalán nem eredményezte az integráció erózióját, sőt, az újszerü megoldások még hatékonyabbá és ellenállóbbá tették az eurózóna müködését. A dezintegráció lehetőségét a szerző a szélsőséges politikák elterjedésétől teszi függővé. A további mélyüléshez pedig lehetséges, hogy újabb válságra lesz szükség ez a lehetőség a koronavírus-járvánnyal talán már itt is van.

Benczes István könyve az integrációelméletek kombinációjának segítségével az európai integráció értelmezésének újszerü keretét adja. Az európai pénzügyi válságra adott reformok kategorizálása alátámasztja azt, hogy ez a keret jól használható összetett folyamatok értelmezésére. Az elméleti keret értéke, hogy nem kész válaszokat ad, hanem szempontokat az integráció történéseinek elemzéséhez. Relevanciája messze túlmutat a Gazdasági és Monetáris Unió kérdésein, és szinte bármely európai szintű közpolitika fejleményeinek értelmezésére alkalmas lehet. A kézirat 2019. márciusban készült el, azóta sok minden történt Európában. A koronavírus okozta válság hatására komoly áttörést jelent az újjáépítési alap kapcsán történő közös hitelfelvétel. Az új költségvetést és a jogállamisági feltételek bevezetését is érdemes kielemezni a könyv elméleti kerete segítségével.

Összességében Benczes István kötete jó szívvel ajánlható szakirodalomként az egyetemi oktatásban, és megkerülhetetlen a témával foglalkozó kutatók számára is.

\section{Győrffy Dóra ${ }^{1}$}

\footnotetext{
${ }^{1}$ DSc, egyetemi tanár Pázmány Péter Katolikus Egyetem Nemzetközi- és Politikatudományi Intézet és Budapesti Corvinus Egyetem, Összehasonlító és Intézményi Gazdaságtan Tanszék.

DOI: 10.14267/RETP2021.02.19
} 